\title{
Handel międzynarodowy a koncepcja zrównoważonego rozwoju
}

Piotr Rubaj*

\section{Wprowadzenie}

Rozwój gospodarczy kraju oraz wzrost bogactwa jego mieszkańców powinny być zawsze nadrzędnym celem polityki gospodarczej rządu. W praktyce jednak różne systemy polityczne mają odmienne priorytety, jeśli chodzi o czerpanie maksymalnych korzyści z zasobów materialnych, intelektualnych i technologicznych. W systemach autorytarnych bardzo często górę biorą partykularne interesy jednostek i wybranych grup społecznych dążących do maksymalizacji wartości posiadanego bogactwa, niekiedy kosztem znacznie liczniejszej pozostałej części społeczeństwa. Historia pokazuje nader liczne przykłady tego typu rządów sekretarzy, dyktatorów, autokratów i oligarchów, którzy mieli na względzie własne interesy i nie liczyli się z dobrem wspólnym. Zazwyczaj ich działania prowadziły do protestów, strajków, a nawet rewolucji. W krajach, w których legitymacją do sprawowania władzy są demokratyczne wybory, a w gospodarce nadrzędnymi wartościami są idea wolnego rynku i wolność wyborów jednostki, najistotniejszą kwestią staje się dobro całego społeczeństwa. Taka polityka gospodarczo-społeczna, prowadzona w krajach demokratycznych począwszy od drugiej połowy XX w., zyskała miano polityki „państwa dobrobytu” lub polityki welfare state ${ }^{1}$. W różnych krajach kształtowały się różne modele tej polityki, począwszy od

\footnotetext{
* Piotr Rubaj - doktor, Katolicki Uniwersytet Lubelski im. Jana Pawła II, Katedra Ekonomii Międzynarodowej, piotr.rubaj@kul.pl

${ }^{1} \mathrm{~W}$ XX w. ukształtowało się kilka modeli polityki welfare state, które pod wpływem przemian politycznych i gospodarczych ewoluowały w różnych kierunkach. Poszczególne modele różniły się zakresem społecznych funkcji państwa oraz sposobem wykonywania ustalonych zadań i formą redystrybucji dochodów. Możemy wyróżnić cztery podstawowe modele ,państwa dobrobytu”: konserwatywno-korporacjonistyczny, liberalny, socjaldemokratyczny i śródziemnomorski.
} 
charakterystycznego dla Ameryki Północnej modelu liberalnego, przez korporacyjny, kultywowany głównie w europejskich krajach kontynentalnych, aż po typowy dla państw skandynawskich model socjaldemokratyczny, postrzegany jako najbardziej opiekuńczy (Rubaj 2013, s. 25).

We współczesnych gospodarkach rynkowych nadrzędną wartością w sprawowaniu władzy stają się dobrobyt jednostki oraz proporcjonalny wzrost bogactwa i poprawa jakości życia całego społeczeństwa. Należy jednak zauważyć, że współczesne welfare state istotnie różni się od modelu propagowanego jeszcze w latach 90. ubiegłego stulecia. Z powodu ewoluującej sytuacji gospodarczej w modelu tym najistotniejszą rolę odgrywały podstawowe społeczne funkcje państwa, tzn. programy transferowe mające na celu zapewnienie minimum bezpieczeństwa socjalnego oraz dostęp do edukacji i służby zdrowia dla całego społeczeństwa. Współcześnie dbałość o opiekuńczy charakter państwa coraz częściej zastępowana jest dążeniem do jego „zrównoważonego rozwoju gospodarczego”. Ma to na celu podkreślenie dużej kompleksowości polityki społecznej, gwarantującej już nie tylko podstawowe programy socjalne, lecz również szeroko rozumiany komfort życia, czyli jakość środowiska naturalnego w miejscu zamieszkania, dostęp do nowoczesnych osiągnięć cywilizacyjnych, takich jak Internet czy telefonia komórkowa, oraz wsparcie jednostki przez państwo na różnych etapach jej rozwoju zawodowego i rodzinnego.

„Zrównoważony rozwój gospodarczy” jest pojęciem znacznie szerszym niż pojęcie „zrównoważony wzrost gospodarczy”, które dotyczy jedynie kwantyfikowalnych efektów działalności gospodarczej. W literaturze toczy się dyskusja na temat tego, w jakim stopniu zrównoważony wzrost gospodarczy wspomaga zrównoważony rozwój, a w jakim stopniu przyczynia się do dewastacji środowiska naturalnego i pogorszenia warunków życia człowieka (Brzoska, Lewandowska 2013, s. 84). I chociaż kwestię tę można rozumieć wielorako, a zakres interpretacyjny pojęcia zrównoważonego rozwoju gospodarczego stale się zmienia (Bluszcz 2018, s. 680), to nie ulega wątpliwości, że osiąganie jego celów bez dodatniej dynamiki wzrostu gospodarczego nie jest możliwe. Recesja w gospodarce powoduje ograniczanie wydatków publicznych, zwiększanie deficytów budżetowych oraz wzrost długu publicznego, co utrudnia lub wręcz uniemożliwia realizację strategicznych zadań zrównoważonego rozwoju. Za logiczny i metodologicznie poprawny można zatem uznać następujący wniosek: bez stabilnej, nowoczesnej i konkurencyjnej gospodarki nie jest możliwy rozwój społeczeństwa jako całości. Stabilność makroekonomicznych parametrów gospodarczych oraz budowanie struktury dochodu narodowego bazującej na sektorach opartych na technologiach i nowoczesnej wiedzy wymagają intensywnej międzynarodowej wymiany handlowej.

Niniejszy artykuł ma zatem na celu przedstawienie roli handlu zagranicznego w gospodarce w kontekście realizacji programów zrównoważonego rozwoju 
ONZ. Zawarta w publikacji metodologia obejmuje analizę zarówno teoretycznych, jak i praktycznych aspektów programów zrównoważonego rozwoju, a także omówienie sposobów pomiaru stopnia ich realizacji oraz czynników determinujących ich rozwój. Wartością dodaną artykułu jest makroekonomiczna analiza celów wspomnianych programów w kontekście handlu międzynarodowego. Dokonując przeglądu literatury, możemy zauważyć, że z jednej strony obfituje ona w opisy i analizy zrównoważonego rozwoju, z drugiej zaś trudno jest znaleźć bezpośrednie odniesienia do roli i znaczenia międzynarodowej wymiany handlowej. Publikacje poruszające te zagadnienia to Sustainable Development: Meaning, History, Principles, Pillars, and Implications For Human Action: Literature Review (Mensah J., Casadevall S.R. 2019) czy też Financial Markets And The Challenges of Sustainable Growth (Janicka M. 2016), która przedstawia kwestię zrównoważonego rozwoju w odniesieniu do zasad funkcjonowania rynków finansowych.

\section{Wzrost gospodarczy a koncepcje zrównoważonego rozwoju}

„Wzrost gospodarczy” jako termin z zakresu ekonomii jest jednym z najważniejszych pojęć pozwalających analizować i porównywać makroekonomiczny poziom rozwoju różnych gospodarek i krajów. Potrzebę stworzenia modelu wzrostu gospodarczego dostrzegli już autorzy pierwszych koncepcji rozwoju ekonomicznego, datowanych na koniec XVIII w., czyli przedstawiciele klasycznej myśli ekonomicznej, do których niewątpliwie można zaliczyć m.in. A. Smitha, D. Ricarda, T. Malthusa czy K. Marksa. Co prawda nie formułowali oni jeszcze w pełni spójnych teorii wzrostu gospodarczego, dostrzegali jednak potrzebę wyodrębnienia czynników, które mają istotny wpływ na rozwój gospodarek rozumiany głównie jako rozwój przemysłu. Ich koncepcje z jednej strony znacznie się różniły, zwłaszcza jeśli chodzi o znaczenie poszczególnych czynników rozwoju gospodarczego - Smith podkreślał rolę produkcji, podzielający to stanowisko Ricardo zwracał uwagę na wpływ pieniądza, Malthus badał efektywny popyt, a Marks koncentrował się na podaży - ale z drugiej strony wszyscy oni dostrzegali konieczność inwestycji, postępu technicznego i wzrostu poziomu wykształcenia zasobów ludzkich (Piętak 2017, s. 54). Angielski ekonomista okresu wielkiego kryzysu gospodarczego lat 30 . XX w. J.M. Keynes również zajmował się problematyką wzrostu gospodarczego, choć u podstaw jego teorii znalazły się kwestie związane bardziej z popytem niż podażą rynkową․ Stworzył on pierwszy krótkookresowy model wzrostu gospodarczego w celu wyjaśnienia przyczyn wysokiego poziomu bezrobocia i niskiego poziomu produkcji obserwowanych w latach głębokiego kryzysu. Podstawowe pytanie, na które starał się odpowiedzieć Keynes,

${ }^{2}$ Szerzej na ten temat: Davidson (2012), Wojtyna (2000). 
brzmiało: dlaczego w krótkim okresie produkcja faktyczna znacznie odbiega od potencjalnej, tzn. takiej, w przypadku której w pełni wykorzystywane są wszystkie czynniki produkcji? W modelu tym wielkość produkcji zależy od zagregowanych wydatków, czyli ogólnej sumy pieniędzy, którą ludzie chcą wydać na dobra i usługi w całej gospodarce, dlatego też model ten nazwany jest modelem popytowym.

Oczywiście efekty tych wczesnych prób wyjaśnienia mechanizmów wzrostu gospodarczego i rozwoju kraju nie mogą jeszcze zostać nazwane spójnymi modelami teorii wzrostu gospodarczego (które pojawiły się dopiero w drugiej połowie XX w.). Modele teorii wzrostu gospodarczego można podzielić na endogeniczne i egzogeniczne. Zwolennikami tych pierwszych są czerpiący z osiągnięć klasycznych teoretyków ekonomii neoklasycy, do których możemy zaliczyć R. Solowa, M. Ramsey'a oraz P. Diamonda. Modelami egzogenicznymi posługiwali się m.in. P. Romer, R. Lucas, S. Rebelo, P. Aghion i P. Howitt. Pierwszym ekonomistą, który sformalizował analizę zjawiska wzrostu gospodarczego, był R. Solow (1956). Przedstawiony przez niego model, wprowadzający do teorii wzrostu neoklasyczną funkcję produkcji, zapoczątkował erę neoklasycznych modeli wzrostu gospodarczego, w których funkcja produkcji opierała się na stałych przychodach ze skali oraz malejącej krańcowej produkcyjności kapitału. Inni neoklasycy rozwijali model Solowa. Ramsey wprowadził do swoich rozważań problem optymalnego poziomu oszczędności ${ }^{3}$, w którym stopa oszczędności jest zmienną endogeniczną, uzależnioną od decyzji konsumentów. Właśnie dlatego główna różnica między modelem Ramseya a modelem Solowa dotyczy kształtowania się stopy oszczędności - w teorii Solowa była ona egzogeniczna, a w podejściu Ramseya kształtuje się endogenicznie na podstawie decyzji optymalizacyjnych podejmowanych przez maksymalizujące użyteczność gospodarstwa domowe. Model Diamonda, podobnie jak modele Solowa i Ramseya, wyjaśnia długookresowy wzrost gospodarczy, ale w przeciwieństwie do nich charakteryzuje się skończonym horyzontem czasowym i uwzględnia zmiany demograficzne, które wpływają na zróżnicowaną użyteczność płynącą z konsumpcji w różnych okresach życia. Próbując znaleźć wspólny mianownik dla modeli neoklasycznych, można zauważyć, że charakteryzują się one neoklasyczną funkcją produkcji zakładającą występowanie malejących przychodów z odtwarzalnych czynników produkcji oraz stałych przychodów ze skali. Modele te świetnie nadają się do wyjaśnienia różnic w poziomach dochodów krajów. Przykładowo model Solowa w wersji rozszerzonej, uwzględniającej różnice w stopie oszczędności, stopie akumulacji kapitału ludzkiego oraz tempie wzrostu liczby ludności, w dużej mierze wyjaśnia różnice w poziomach dochodów per capita między państwami.

${ }_{3}^{3}$ Jego model rozwijany był przez D. Cassa i T.C. Koopmansa. 
W przeciwieństwie do omówionych modeli neoklasycznych zaprezentowane poniżej wybrane modele endogeniczne objaśniają głównie determinanty długookresowego wzrostu gospodarczego, jednak w poszczególnych modelach wzrost ten zależy od różnych czynników. Większe inwestycje w kapitał ludzki, większy zasób kapitału ludzkiego, wydłużenie czasu pracy, większe nakłady na B + R oraz wyższa efektywność prac badawczo-rozwojowych to tylko niektóre determinanty zapewniające, zgodnie z teoriami endogenicznymi, szybszy wzrost gospodarczy. Romer jako pierwszy wprowadził do neoklasycznej funkcji produkcji efekty zewnętrzne kapitału, dzięki czemu powstała zależność pomiędzy rosnącymi przychodami skali a czynnikami produkcji oraz stałymi przychodami skali względem kapitału, co z kolei stworzyło warunki do badania endogenicznego wzrostu gospodarczego. Lucas zaproponował dwusektorowy model wzrostu gospodarczego uwzględniający dwa typy kapitału - wykorzystywany w procesie produkcyjnym kapitał fizyczny oraz kapitał ludzki, który wpływa na wzrost produktywności pracy i kapitału fizycznego - wyjaśniający istnienie różnic w rozwoju gospodarczym pomiędzy poszczególnymi krajami. Kraje charakteryzujące się niskim poziomem kapitału rozwijają się wolniej od państw dysponujących większym jego zasobem, a różnica w poziomie rozwoju pomiędzy krajami bogatymi i biednymi z czasem się powiększa. W modelu Rebela (Rebelo 1991), podobnie jak w koncepcji Lucasa, do wyjaśnienia mechanizmu wzrostu gospodarczego wykorzystane zostały zależności dwusektorowe uwzględniające podział na kapitał fizyczny i kapitał ludzki. Rebelo wskazuje, że to właśnie działania państwa w dużym stopniu wyjaśniają różnice w tempie wzrostu gospodarczego między krajami. Podejście to różni się od koncepcji Lucasa w dwóch kwestiach. Po pierwsze, w modelu Rebela nie występują efekty zewnętrzne ani związane z nimi rosnące przychody na poziomie całej gospodarki. Po drugie, w akumulacji kapitału ludzkiego jest również wykorzystywany kapitał fizyczny, a nie, jak w koncepcji Lucasa, jedynie kapitał ludzki.

Prezentowane modele endogeniczne i egzogeniczne nie wyczerpują kwestii koncepcji i modeli wzrostu gospodarczego - ukazują jedynie chronologiczną i metodologiczną ewolucję w podejściu do tego zagadnienia ${ }^{4}$. Kolejne opracowania przedstawiają wpływ innych czynników na poziom wzrostu gospodarczego. Przykładowo G.S. Becker podejmuje próbę znalezienia korelacji pomiędzy inwestycjami w kapitał ludzi a przyrostem ludności, R.J. Barro zwraca uwagę na problem długu publicznego i jego wpływ na wzrost gospodarczy, a J.L. Gallup analizuje to, jak na wzrost gospodarczy wpływa położenie geograficzne (Piętak 2017, s. 54).

W przeciwieństwie do ekonometrycznych modeli wzrostu gospodarczego pojęcie zrównoważonego rozwoju gospodarczego jest znacznie bardziej kompleksowe i nie da się zastosować w jego przypadku ujednoliconych miar. Koncepcję

${ }^{4}$ Szerzej na ten temat: Tokarski 2005. 
zrównoważonego rozwoju analizuje się zazwyczaj w trzech wymiarach: ekonomicznym, społecznym i środowiskowym. Wymiar ekonomiczny rozumiany jest przede wszystkim jako zrównoważony wzrost gospodarczy mierzony dynamiką wzrostu PKB, społeczny gwarantuje przede wszystkim wysoki poziom zatrudnienia oraz stabilność indywidualnych dochodów, a środowiskowy odnosi się do warunków życia i zachowania najwyższych standardów ochrony środowiska naturalnego (Brzoska, Lewandowska 2013, s. 84). Celem polityki zrównoważonego rozwoju jest więc dążenie do osiągania trwałej dodatniej dynamiki wzrostu gospodarczego w warunkach sprzyjających ograniczaniu nierówności społecznych oraz aktywne kształtowanie proekologicznej polityki indywidualnej i instytucjonalnej.

Chociaż koncepcja zrównoważonego rozwoju pojawiła się w latach 70. ubiegłego stulecia, a pierwsze jej postulaty zostały przedstawione na Szczycie Ziemi w Rio de Janeiro w 1992 r., to w rzeczywistości weszła do programów rozwojowych krajów i organizacji dopiero na początku XXI w. (Mikuła 2016). W 2000 r. na Konferencji Narodów Zjednoczonych opracowane zostały, a następnie przyjęte przez ONZ milenijne zadania, mające przede wszystkim na celu wyeliminowanie skrajnego ubóstwa, ograniczenie rozprzestrzeniania się HIV/AIDS oraz zapewnienie powszechnego dostępu do edukacji i podstawowej opieki zdrowotnej. Sformułowano 8 celów, które obejmowały 21 zadań. Chociaż trzy z ośmiu celów osiągnięto przed końcowym terminem wyznaczonym na rok 2015, to ogólny postęp w ich realizacji $\mathrm{w}$ poszczególnych regionach i krajach był niedostateczny i niesatysfakcjonujący, w związku z czym podjęto decyzję o kontynuacji prac. W czerwcu 2012 r. w Rio de Janeiro odbyła się kolejna Konferencja Narodów Zjednoczonych, na której opracowano nowe cele zrównoważonego rozwoju dla świata.

We wrześniu 2015 r. w siedzibie ONZ w Nowym Jorku odbył się szczyt Agendy Zrównoważonego Rozwoju 2030, w którym wzięli udział szefowie rządów i głowy państw ponad 100 krajów świata oraz przedstawiciele grup religijnych, biznesu i społeczeństwa. Efektem szczytu było przyjęcie agendy na rzecz zrównoważonego rozwoju 2030 zawierającej 17 celów. Głównym celem programu jest eliminacja ubóstwa na świecie i podnoszenie standardów życia w wyniku promowania zrównoważonego rozwoju w trzech obszarach: społecznym, gospodarczym i ochrony środowiska. Odpowiedzialność za realizację wspomnianych zadań spoczywa na wszystkich sygnatariuszach porozumienia i ma charakter ponadnarodowy.

Również Unia Europejska, która także uznaje potrzebę wprowadzenia harmonijnego, przyjaznego obywatelom i środowisku naturalnemu procesu rozwoju gospodarczego, sformułowała cele zrównoważonego rozwoju Wspólnoty. Początkowo znalazły one odzwierciedlenie w zapisach Traktatu amsterdamskiego ${ }^{5}$,

\footnotetext{
5 Traktat amsterdamski został podpisany w Amsterdamie 2.10.1997 r. i wszedł w życie 1.05.1999 r. Traktat ten zmienił Traktat o Unii Europejskiej, traktaty ustanawiające Wspólnoty Europejskie i niektóre związane z nimi akty. W założeniu miał dostosowywać unijne traktaty do planowanego poszerzenia UE oraz zbliżyć Unię do obywateli, jednak konferencja międzyrządowa przygotowująca
} 
a następnie w Strategii lizbońskiej ${ }^{6}$ oraz Strategii „Europa 2020” i dotyczyły realizacji określonych kwantyfikowalnych zadań dotyczących gospodarki, społeczeństwa i środowiska. Cele te zostały szczegółowo opisane w komunikacie Komisji Europejskiej z dn. 3.03.2010 r.

\section{Wskaźniki kwantyfikacji wzrostu gospodarczego i zrównoważonego rozwoju}

Odwołując się do prac teoretyków ekonomii, można stwierdzić, że ze wzrostem gospodarczym $y_{k}$ mamy do czynienia wtedy, kiedy stopa oszczędności $s$ i współczynnika kapitałowego $v$, pomniejszona o deprecjację kapitału $\delta$, przewyższa stopę wzrostu liczby ludności, co ilustruje następujący zapis:

$$
Y_{k}=\frac{s}{v}-\delta>n
$$

Zazwyczaj w modelach wzrostu gospodarczego zakłada się egzogeniczność zmiennych $\delta$ i $n$ opisujących deprecjację kapitału oraz przyrost siły roboczej (Piętak 2017, s. 43). Zmienne $v$ is, w zależności od szkoły ekonomicznej, mogą być endogeniczne lub egzogeniczne. Do tych pierwszych zaliczyli je w swoich rozważaniach R. Solow, M. Ramsey i P. Diamond, a do drugiej grupy - P. Romer, R. Lucas, S. Rebelo, a także P. Aghion i P. Howitt. Teorie wzrostu gospodarczego, zarówno te historyczne, jak i współczesne, stawiają sobie za cel poszukiwanie określonych paradygmatów ekonomicznych, które w kwantyfikowalnym zapisie matematycznym pozwalają analizować określone zmienne i ich wpływ na dynamikę wzrostu gospodarczego. Są to jednak tylko teorie, które nie pozwalają na w pełni obiektywne i ujednolicone porównywanie procesów wzrostu gospodarczego. $Z$ pomocą przychodzą tutaj bardziej powszechne i wystandaryzowane miary makroekonomiczne, które dają możliwość prowadzenia analiz ekonomicznych na podstawie ujednoliconych regul, metodologii i standardów. Podstawowym miernikiem efektywności działań gospodarki danego kraju jest analiza dynamiki zmian wartości PKB w czasie przy użyciu cen realnych, tzn. z określonego

traktat nie zdołała wypracować dostatecznie daleko idących zmian, w związku z czym postanowiono, że właściwa rewizja traktatów pod kątem przygotowania do akcesji państw Europy Środkowo-Wschodniej nastąpi w późniejszym terminie.

${ }^{6}$ Strategia Lizbońska - plan rozwoju Unii Europejskiej na lata 2000-2010 przyjęty przez Radę Europejską na posiedzeniu w Lizbonie w marcu $2000 \mathrm{r}$.

7 Strategia Europa 2020 dotyczy wzrostu społeczno-gospodarczego Unii Europejskiej do roku 2020. Została przyjęta 3.03.2010 r. przez Komisję Europejską w celu stymulowania rozwoju gospodarek państw tego ugrupowania. 
roku. Miara ta - jako jeden z elementów tzw. systemu rachunków narodowych ${ }^{8}$ - jest powszechnie stosowana jako miernik tempa rozwoju gospodarczego. Jej kolejną zaletą, oprócz powszechności stosowania, jest ujednolicona metodologia kwantyfikacji. Należy również podkreślić, że wartość PKB często stosuje się jako punkt odniesienia do prezentacji innych efektów polityki gospodarczej, np. długu publicznego, wydatków na badania i rozwój, wydatków na edukację lub ochronę zdrowia jako procent PKB.

Kwantyfikacja wyników prowadzenia polityki zrównoważonego rozwoju jest zagadnieniem znacznie szerszym i bardziej kompleksowym niż pomiar efektywności programu zrównoważonego wzrostu gospodarczego. Złożoność pojęcia „polityka zrównoważonego rozwoju” sprawia, że również wskaźniki stosowane do oceny jej efektywności są o wiele bardziej złożone i zróżnicowane. Miary te determinowane są określonymi celami gospodarczymi, społecznymi i środowiskowymi polityki zrównoważonego rozwoju, które prezentuje Tabela 1.

Tabela 1. Cele zrównoważonego rozwoju ONZ do roku $2030^{9}$

\begin{tabular}{|c|c|c|}
\hline $\mathrm{Nr}$ & Cel glówny & Najważniejsze działania i miary \\
\hline $\mathrm{C} 1$ & $\begin{array}{l}\text { Wyeliminować ubóstwo we wszystkich } \\
\text { jego formach na całym świecie }\end{array}$ & $\begin{array}{l}\text { Do } 2030 \text { roku wyeliminować skrajne ubóstwo } \\
\text { na całym świecie aktualnie mierzone jako utrzy- } \\
\text { mywanie się za mniej niż } 1,25 \text { USD dziennie }\end{array}$ \\
\hline $\mathrm{C} 2$ & $\begin{array}{l}\text { Wyeliminować głód, osiągnąć bez- } \\
\text { pieczeństwo żywnościowe i lepsze } \\
\text { odżywianie oraz promować zrównowa- } \\
\text { żone rolnictwo }\end{array}$ & $\begin{array}{l}\text { Do } 2030 \text { roku wyeliminować głód i zapewnić } \\
\text { wszystkim ludziom, w szczególności ubogim } \\
\text { i narażonym na zagrożenia, w tym niemowla- } \\
\text { kom, dostęp do bezpiecznej, pożywnej żywno- } \\
\text { ści w wystarczającej ilości przez cały rok }\end{array}$ \\
\hline C3 & $\begin{array}{l}\text { Zapewnić wszystkim ludziom w każ- } \\
\text { dym wieku zdrowe życie oraz promo- } \\
\text { wać dobrobyt }\end{array}$ & $\begin{array}{l}\text { Do } 2030 \text { roku zmniejszyć globalny wskaźnik } \\
\text { śmiertelności okołoporodowej do poziomu } \\
\text { mniejszego niż } 70 \text { przypadków na } 100 \text { tys. } \\
\text { żywych urodzeń }\end{array}$ \\
\hline $\mathrm{C} 4$ & $\begin{array}{l}\text { Zapewnić wszystkim edukację wyso- } \\
\text { kiej jakości oraz promować uczenie się } \\
\text { przez całe życie }\end{array}$ & $\begin{array}{l}\text { Do } 2030 \text { roku zapewnić wszystkim dziewczę- } \\
\text { tom i chłopcom ukończenie nieodpłatnej, spra- } \\
\text { wiedliwej, dobrej jakości edukacji na poziomie } \\
\text { podstawowym i ponadpodstawowym, prowa- } \\
\text { dzącej do efektywnych wyników w nauce }\end{array}$ \\
\hline C5 & $\begin{array}{l}\text { Osiągnąć równość płci oraz wzmocnić } \\
\text { pozycję kobiet i dziewcząt }\end{array}$ & $\begin{array}{l}\text { Zakończyć dyskryminację we wszystkich } \\
\text { formach wobec kobiet i dziewcząt na całym } \\
\text { świecie }\end{array}$ \\
\hline C6 & $\begin{array}{l}\text { Zapewnić wszystkim ludziom dostęp } \\
\text { do wody i warunków sanitarnych } \\
\text { dzięki zrównoważonej gospodarce } \\
\text { zasobami wodnymi }\end{array}$ & $\begin{array}{l}\text { Do } 2030 \text { roku zapewnić powszechny i sprawie- } \\
\text { dliwy dostęp do bezpiecznej wody pitnej po } \\
\text { przystępnej cenie }\end{array}$ \\
\hline
\end{tabular}

\footnotetext{
${ }^{8}$ System rachunków narodowych (national account systems) - uporządkowany system rachunków makroekonomicznych opracowanych według obowiązujących norm i reguł statystycznych, służący do pomiaru efektów działalności gospodarczej w krajach o gospodarce rynkowej.

9 Sustainable Development Goals (SDG's) - agenda 17 celów zrównoważonego rozwoju oraz związanych z nimi 169 zadań, które mają zostać osiągnięte przez świat do $2030 \mathrm{r}$.
} 


\begin{tabular}{|c|c|c|}
\hline $\mathrm{Nr}$ & Cel główny & Najważniejsze dzialania i miary \\
\hline $\mathrm{C} 7$ & $\begin{array}{l}\text { Zapewnić wszystkim dostęp do sta- } \\
\text { bilnej, zrównoważonej i nowoczesnej } \\
\text { energii po przystępnej cenie }\end{array}$ & $\begin{array}{l}\text { Do } 2030 \text { roku podwoić wskaźnik wzrostu glo- } \\
\text { balnej efektywności zużycia energii }\end{array}$ \\
\hline $\mathrm{C} 8$ & $\begin{array}{l}\text { Promować stabilny, zrównoważony } \\
\text { i inkluzywny wzrost gospodarczy, } \\
\text { pełne i produktywne zatrudnienie oraz } \\
\text { godną pracę dla wszystkich ludzi }\end{array}$ & $\begin{array}{l}\text { Utrzymać wzrost gospodarczy na jednego } \\
\text { mieszkańca, biorąc pod uwagę krajowe uwa- } \\
\text { runkowania; osiągnąc i utrzymać przynajmniej } \\
\text { 7-proc. roczny wzrost PKB w krajach najmniej } \\
\text { rozwiniętych }\end{array}$ \\
\hline C9 & \begin{tabular}{|l|} 
Budować stabilną infrastrukturę, \\
promować zrównoważone uprzemysło- \\
wienie oraz wspierać innowacyjność
\end{tabular} & $\begin{array}{l}\text { Promować inkluzywną i zrównoważoną indu- } \\
\text { strializację; do } 2030 \text { roku znacznie zwiększyć } \\
\text { udział przemysłu w zatrudnieniu i wytwarzaniu } \\
\text { PKB, biorąc pod uwagę uwarunkowania kra- } \\
\text { jowe; podwoić ten udział w krajach najsłabiej } \\
\text { rozwiniętych }\end{array}$ \\
\hline $\mathrm{C} 10$ & $\begin{array}{l}\text { Zmniejszyć nierówności w krajach } \\
\text { i między krajami }\end{array}$ & $\begin{array}{l}\text { Zmniejszyć nierówności w krajach i między } \\
\text { krajami }\end{array}$ \\
\hline C11 & $\begin{array}{l}\text { Uczynić miasta i osiedla ludzkie } \\
\text { miejscami bezpiecznymi, stabilnymi, } \\
\text { zrównoważonymi oraz sprzyjającymi } \\
\text { włączeniu społecznemu }\end{array}$ & $\begin{array}{l}\text { Uczynić miasta i osiedla miejscami bezpieczny- } \\
\text { mi, stabilnymi, zrównoważonymi oraz sprzyja- } \\
\text { jącymi włączeniu społecznemu }\end{array}$ \\
\hline $\mathrm{C} 12$ & $\begin{array}{l}\text { Zapewnić wzorce zrównoważonej } \\
\text { konsumpcji i produkcji }\end{array}$ & $\begin{array}{l}\text { Zapewnić wzorce zrównoważonej konsumpcji } \\
\text { i produkcji }\end{array}$ \\
\hline $\mathrm{C} 13$ & $\begin{array}{l}\text { Podjać pilne działania w celu prze- } \\
\text { ciwdziałania zmianom klimatu i ich } \\
\text { skutkom }\end{array}$ & $\begin{array}{l}\text { Podjąć pilne działania w celu przeciwdziałania } \\
\text { zmianom klimatu i ich skutkom }\end{array}$ \\
\hline $\mathrm{C} 14$ & $\begin{array}{l}\text { Chronić oceany, morza i zasoby mor- } \\
\text { skie oraz wykorzystywać je w sposób } \\
\text { zrównoważony }\end{array}$ & $\begin{array}{l}\text { Chronić oceany, morza i zasoby morskie oraz } \\
\text { wykorzystywać je w sposób zrównoważony }\end{array}$ \\
\hline $\mathrm{C} 15$ & \begin{tabular}{|l|} 
Chronić, przywrócić oraz promować \\
zrównoważone użytkowanie ekosyste- \\
mów lądowych, zrównoważone gospo- \\
darowanie lasami, zwalczać pustynnie- \\
nie, powstrzymywać i odwracać proces \\
degradacji gleby oraz powstrzymać \\
utratę różnorodności biologicznej \\
\end{tabular} & $\begin{array}{l}\text { Chronić, przywrócić oraz promować zrówno- } \\
\text { ważone użytkowanie ekosystemów lądowych, } \\
\text { zrównoważone gospodarowanie lasami, zwal- } \\
\text { czać pustynnienie, powstrzymywać i odwracać } \\
\text { proces degradacji gleby oraz powstrzymać } \\
\text { utratę różnorodności biologicznej }\end{array}$ \\
\hline $\mathrm{C} 16$ & $\begin{array}{l}\text { Promować pokojowe i inkluzywne } \\
\text { społeczeństwa, zapewnić wszystkim } \\
\text { ludziom dostęp do wymiaru sprawie- } \\
\text { dliwości oraz budować na wszystkich } \\
\text { szczeblach skuteczne i odpowiedzial- } \\
\text { ne instytucje sprzyjające włączeniu } \\
\text { społecznemu }\end{array}$ & $\begin{array}{l}\text { Promować pokojowe i inkluzywne społeczeń- } \\
\text { stwa, zapewnić wszystkim ludziom dostęp } \\
\text { do wymiaru sprawiedliwości oraz budować } \\
\text { na wszystkich szczeblach skuteczne i odpo- } \\
\text { wiedzialne instytucje sprzyjające włączeniu } \\
\text { społecznemu }\end{array}$ \\
\hline $\mathrm{C} 17$ & $\begin{array}{l}\text { Wzmocnić środki wdrażania i ożywić } \\
\text { globalne partnerstwo na rzecz zrówno- } \\
\text { ważonego rozwoju }\end{array}$ & $\begin{array}{l}\text { Wzmocnić środki wdrażania i ożywić globalne } \\
\text { partnerstwo na rzecz zrównoważonego rozwoju }\end{array}$ \\
\hline
\end{tabular}

Źródło: opracowanie własne na podstawie www.polskapomoc.gov.pl/Agenda,Zrownowazonego,Rozwoju,2030,2370.html; www.un.org.pl/cel2 (data dostępu: 12.04.2020). 
Do ocenienia efektów polityki zrównoważonego rozwoju gospodarczego, konieczne jest wykorzystanie licznych miar, wskaźników i celów jakościowych, które nie zawsze są w pełni kwantyfikowalne. Znaczna część oczekiwanych celów wspomnianej polityki ma charakter jakościowy i jest trudna do zmierzenia. Przykładowo cele C2-C5 - odnoszące się do ograniczenia poziomu głodu, poprawy warunków bytowych, powszechnego dostępu do edukacji w różnych okresach życia oraz do równości płci - są jak najbardziej uzasadnione społecznie, ale w różnych warunkach i różnych krajach mogą być odmiennie definiowane, a to może utrudniać w pełni wartościowe ujednolicanie celów. Nasuwa się więc wniosek, żeby znacznie bardziej precyzyjnie kwantyfikowalna polityka stałego wzrostu gospodarczego nie była celem samym w sobie, tylko środkiem, który pozwoli osiągnąć liczne cele zawarte w programie Zrównoważonego Rozwoju ONZ. W tym sensie istnieje koherentny związek pomiędzy tymi dwoma programami.

W odpowiedzi na Agendę 2030, zawierającą 17 celów zrównoważonego rozwoju, Europejska Komisja przyjęła w listopadzie 2016 r. dokument Kolejne kroki w kierunku zrównoważonej przyszłości Europy, w którym nakreśliła plan działań w celu wprowadzenia w życie założeń Agendy 2030. Dokument ten, a także późniejszy, z 2019 r., zatytułowany W kierunku zrównoważonej Europy 2030, określają priorytety polityki państw Wspólnoty realizującej postulaty programu zrównoważonego rozwoju. Siedem z 27 państw członkowskich UE znajduje się w pierwszej dziesiątce światowego rankingu indeksu celów zrównoważonego rozwoju, a wszystkie państwa członkowskie UE plasują się w pierwszej pięćdziesiątce (spośród 156 krajów), dlatego też ich cele muszą się różnić od celów krajów na niższym poziomie rozwoju gospodarczego i społecznego. Wśród priorytetów działań Wspólnoty na lata 2014-2019 znalazły się zatem takie działania jak: (1) zatrudnienie, wzrost gospodarczy i inwestycje, (2) jednolity rynek cyfrowy, (3) unia energetyczna i klimat, (4) rynek wewnętrzny, (5) pogłębiona i bardziej sprawiedliwa unia gospodarcza i walutowa, (6) zrównoważona i postępowa polityka handlowa w celu wykorzystania możliwości płynących z globalizacji, (7) sprawiedliwość i prawa podstawowe, (8) migracje, (9) silniejsza pozycja na arenie międzynarodowej oraz (10) bardziej demokratyczna Unia. Mierzalność tych celów jest bardzo zróżnicowana - od tych całkowicie kwantyfikowalnych, takich jak dynamika wzrostu gospodarczego, zatrudnienie, inwestycje, konsumpcja, zużycie energii, przez stricte jakościowe, dotyczące sprawiedliwości i poszanowania prawa, aż do politycznych, dotyczących umów handlowych i migracji. W związku z tym miary stosowane do oceny efektów realizacji poszczególnych postulatów są dostosowane do możliwości pomiaru i monitorowania zachodzących zmian, zazwyczaj wyrażane są procentowo w stosunku do wartości bazowych i rozpatrywane w trendach krótko- i długoterminowych (Sustainable development... 2018, s. 24). Przykładowo w przypadku celu pierwszego, dotyczącego ograniczania poziomu ubóstwa, rozpatrywane są takie kryteria jak liczba ludności 
zagrożona ubóstwem lub wykluczeniem społecznym, liczba osób zagrożona ubóstwem z uwzględnieniem transferów pomocy socjalnej czy ludności z wysokim wskaźnikiem deprywacji materialnej. W przypadku celu trzeciego, odnoszącego się do jakości życia i zdrowia, przykładowe wskaźniki dotyczą oczekiwanej długości życia w momencie narodzin, szeroko rozumianego poczucia zdrowia, intensywności czynników stanowiących zagrożenie dla życia czy też dostępu do służby zdrowia. Jeśli chodzi o kwestie zrównoważonego rozwoju związane z gospodarką i konsumpcją, o których mowa w celu dwunastym, to wskaźniki dotyczą m.in. emisji $\mathrm{CO}_{2}$ do atmosfery, zużycia środków chemicznych, produkcji energii elektrycznej ze źródeł odnawialnych oraz procesów zarządzania zasobami wody. W kwestii ekologii, uwzględnionej m.in. w celu C15, najważniejsze wskaźniki odnoszą się do stanu ekosystemów, w tym procentowo do obszarów zalesionych, oraz jakości wody i gleby, stopnia degradacji środowiska naturalnego oraz wielkości obszarów objętych programem Natura 2000.

Podsumowując, możemy zauważyć, że wskaźniki kwantyfikacji wzrostu gospodarczego i zrównoważonego rozwoju są bardzo zróżnicowane. Pierwsze z nich bazują na podstawowych miarach makroekonomicznych, a drugie są wskaźnikami jakościowymi, odnoszącymi się do liczbowo lub procentowo zdefiniowanych wartości okresu referencyjnego, które zazwyczaj analizowane są w trendach krótko- i długookresowych, co pozwala skutecznie monitorować i intepretować zachodzące zmiany.

\section{Handel międzynarodowy jako czynnik stabilizujący zrównoważony rozwój gospodarczy}

Jak już nadmieniono w rozważaniach dotyczących zrównoważonego wzrostu i zrównoważonego rozwoju gospodarczego, znaczenie tych dwóch pojęć istotnie się różni, choć dotyczy powiązanych ze sobą procesów. Zrównoważony wzrost gospodarczy to przede wszystkim w pełni mierzalny przyrost wartości PKB w zdefiniowanych okresach czasowych, a rozwój to bardzo kompleksowe ujęcie procesu harmonijnego kształtowania się warunków życia mieszkańców całego świata w różnych systemach politycznych i gospodarczych. Przedstawione wcześniej miary i wskaźniki pozwalają kwantyfikować i porównywać wspomniane procesy, ale nie odpowiadają na pytanie, jak istotna jest rola handlu międzynarodowego i innych powiązań zagranicznych w procesie harmonijnego rozwoju gospodarki światowej. Problem ten można rozpatrywać dwojako - z makroekonomicznego punktu widzenia, w którym system rachunków narodowych powiązany jest z dynamiką wzrostu gospodarczego, lub ze względu na osiągnięcie celów zrównoważonego rozwoju. Miary narodowe to dokładnie opisane w makroekonomii wskaźniki gospodarcze odnoszące się do pomiaru efektywności działań 
gospodarczych. Handel międzynarodowy, wpływając na dochód narodowy kraju, istotnie oddziałuje na poziom życia i bogactwa jego mieszkańców. Dzięki dodatniemu saldu bilansu handlowego rośnie wartość PNB, a tym - dochodu narodowego. Wspomniane zależności możemy zapisać za pomocą dwóch powszechnie znanych równań tożsamościowych z zakresu makroekonomii:

$$
\begin{gathered}
Y=C+I+G+E x N \text { oraz } \\
Y=C+I+G+E x N+N I V G,
\end{gathered}
$$

gdzie odpowiednio: $Y$ w pierwszym równaniu to wartość $\mathrm{PKB}$, a w drugim - PNB, $C$ - konsumpcja publiczna i prywatna, $I$ - inwestycje brutto, $G$ - wydatki rządowe, ExN - saldo netto eksportu, $N I V G$ - saldo netto z tytułu własności zagranicznych środków produkcji (Milewski 2018).

Interesujące nas zmienne to $(E x N, N I V P)$, które w zależności od osiąganych wartości zmniejszają lub zwiększają wartość PKB oraz PNB, a tym samym dochodu narodowego. Ta ostatnia wartość, podzielona per capita, oczywiście świadczy o poziomie dobrobytu mieszkańców, a więc odnosi się do opisywanego wcześniej modelu welfare state lub powszechnie obecnie realizowanej polityki zrównoważonego rozwoju. Wartość dochodu narodowego jest również bardzo istotna w przypadku możliwości inwestycyjnych, a więc możliwości rozwoju gospodarki i stabilizowania wzrostu gospodarczego.

Konkretne odniesienia do handlu międzynarodowego oraz internacjonalizacji światowych powiązań gospodarczych odnajdujemy w ogólnych i szczegółowych celach zrównoważonego rozwoju. Cel ósmy odnosi się właśnie do gospodarki i formułuje postulat stabilnego, zrównoważonego, inkluzywnego wzrostu gospodarczego, pełnego i produktywnego zatrudnienia oraz godnej pracy dla wszystkich ludzi. W celach szczegółowych tego punktu znajdujemy również takie wyzwania jak zwiększanie wydajności gospodarczej w wyniku dywersyfikacji, modernizację technologiczną oraz innowacje, wzrost efektywności wykorzystania bogactw naturalnych w globalnej konsumpcji i produkcji oraz dążenie do zerwania z zależnością między wzrostem gospodarczym a degradacją środowiska.

Niewątpliwie handel międzynarodowy jest koniecznym warunkiem rozwoju poszczególnych krajów i regionów. Dostęp do wielu rynków, brak barier w handlu, możliwość korzystania z efektów skali to tylko wybrane korzyści płynące z internacjonalizacji światowych powiązań gospodarczych. Należy jednak zauważyć, że korzyści te są niekiedy kontestowane przez część ekonomistów, którzy zwracają uwagę na ich wyraźną asymetryczność i znacznie większe korzyści dla krajów wysoko rozwiniętych niż tych wschodzących lub rozwijających się (Stiglitz 2016, s. 45). Bardziej szczegółowe postulaty dotyczące rozwoju handlu międzynarodowego możemy znaleźć w punktach 17.10, 17.11 i 17.12 celu 17 . postulują one odpowiednio: 
1) promowanie powszechnego, opartego na zasadach, otwartego, niedyskryminującego i sprawiedliwego wielostronnego systemu handlowego w ramach Światowej Organizacji Handlu, w tym w wyniku negocjacji Agendy Rozwoju z Doha;

2) znaczące zwiększenie eksportu krajów rozwijających się, ze szczególnym uwzględnieniem podwojenia udziału krajów najsłabiej rozwiniętych, w globalnym eksporcie do 2020 roku;

3) terminowe wdrożenie trwałego bezcłowego i bezkwotowego dostępu do rynku dla wszystkich najsłabiej rozwiniętych krajów, zgodnie $\mathrm{z}$ decyzjami Światowej Organizacji Handlu, w tym w wyniku zapewnienia przejrzystych, prostych i przyczyniających się do ułatwienia dostępu do rynków preferencyjnych reguł pochodzenia mających zastosowanie do przywozu z krajów najsłabiej rozwiniętych.

Przekaz tych celów jest niewątpliwie jasny, precyzyjny i spójny, a przede wszystkim odnosi się do potrzeby dalszej liberalizacji światowego handlu w duchu porozumień WTO, szerszego dostępu krajów słabiej rozwiniętych do światowego rynku oraz unikania stosowania barier i środków protekcji w handlu. Inne punkty celu 17 dotyczą nie mniej ważnych zagadnień o wymiarze międzynarodowym: C17.1-C17.5 postulują zwiększenie kwoty środków finansowych na pomoc krajom rozwijającym się, C17.6-C17.9 ściślejszą współpracę w dziedzinie technologii i najnowszych osiągnięć techniki, a C17.13-C17.7 odnoszą się do spójności polityczno-instytucjonalnej oraz partnerstwa wielostronnego (Agenda 2030).

Rola, znaczenie i odziaływanie światowego handlu międzynarodowego oraz potrzeba bliskiej współpracy z krajami najsłabiej rozwiniętymi akcentowane są również $\mathrm{w}$ celach $2 \mathrm{~B}, 3 \mathrm{~B}, 8 \mathrm{~A}$ zrównoważonego rozwoju. W pierwszym $\mathrm{z}$ nich zwrócono uwagę na potrzebę ograniczania restrykcji handlowych i nieprawidłowości na światowych rynkach rolnych przede wszystkim w wyniku równoczesnej likwidacji wszystkich form rolnych subwencji eksportowych i innych środków wywozowych o analogicznym działaniu, zgodnie z mandatem Rundy z Doha. Kolejny cel odnosi się do konieczności wspierania badań i prac nad stworzeniem nowych szczepionek i lekarstw przeciwko chorobom zakaźnym i niezakaźnym, które dotykają przede wszystkim ludność krajów rozwijających się. Postuluje ponadto, zgodnie z porozumieniami międzynarodowymi, potrzebę zapewnienia dostępu do podstawowych lekarstw i szczepionek po przystępnej cenie. Ostatni cel dotyczy udzielania większego wsparcia krajom rozwijającym się, w szczególności państwom najsłabiej rozwiniętym, przez społeczność międzynarodową.

Reasumując, należy wyraźnie podkreślić istotną rolę handlu międzynarodowego w osiąganiu celów zrównoważonego rozwoju, przede wszystkim w utrzymaniu stabilnej dynamiki wzrostu gospodarczego, która jest warunkiem osiągnięcia większości zaplanowanych rezultatów. 
Odniesienia do handlu międzynarodowego odnajdujemy również w strategicznych działaniach programu Europa 2030. Komisja Europejska w dokumencie, który rozpoczął w 2017 r. debatę W kierunku zrównoważonej Europy 2030, podkreśla, że warunkiem niezbędnym do osiągnięcia zdefiniowanych celów jest m.in. otwarta i oparta na zasadach wymiana handlowa. Autorzy dokumentu odpowiednio interpretują ten postulat i wyjaśniają, że promując międzynarodowe zasady i światowe normy zgodne z celami zrównoważonego rozwoju oraz gwarantując wszystkim odnoszenie korzyści z handlu, możemy przyczynić się do stworzenia zrównoważonej Europy w zrównoważonym świecie.

Również w innych źródłach i opracowaniach naukowych znajdujemy odniesienia do korzyści płynących z intensyfikacji międzynarodowej wymiany handlowej. Pisząc o relacjach między handlem międzynarodowym a osiągnięciem celów zrównoważonego rozwoju, Dupuy powołuje się na różne teorie wzrostu gospodarczego (Heckschera-Ohlina, Baldwina, Stolpera-Samuelsona, Grossmana oraz Kruegera) i podkreśla, że wolny handel dynamizuje rozwój gospodarczy, pozwala na wykorzystanie przewag komparatywnych, umożliwia lepszą alokację zasobów i wreszcie - wyraźny wzrost dochodów i bogactwa społeczeństwa (Dupuy 2014, s. 403). Ponadto w międzynarodowych raportach odnajdujemy analizy relacji między rozwojem handlu a osiąganiem celów zrównoważonego rozwoju. Przykładowo Win-Win Raport bardzo głęboko wnika w kwestie dotyczące równości społecznej, reedukacji dotyczącej biedy, ochrony środowiska oraz efektywnych możliwości tworzenia nowych miejsc pracy (Dupuy 2014, s. 405).

\section{Podsumowanie}

Problematyka sposobów pomiaru efektywności działań gospodarczych nie jest nowa, gdyż jej początki sięgają drugiej połowy XIX w. i rozważań pierwszych teoretyków myśli ekonomicznej. Odnosi się ona do konieczności zdefiniowania mechanizmów determinujących gospodarczy rozwój kraju oraz sposobów pomiaru tego procesu. W różnych okresach różnie interpretowano te zagadnienia, nadając mniejsze lub większe znaczenie czynnikom endogenicznym i egzogenicznym. Współczesne teorie dostrzegają nadrzędną rolę wiedzy oraz wykształcenia kapitału ludzkiego i głównie na tej podstawie wyjaśniają istotne różnice w poziomie rozwoju różnych krajów.

To właśnie dążenie do zapewnienia harmonijnego, stabilnego, tj. bez znacznych wahań koniunkturalnych i zawirowań gospodarczych, wzrostu gospodarczego stało się podstawą XXI-wiecznych postulatów zrównoważonego rozwoju. Geneza tej polityki sięga połowy XX w., kiedy to zaczęto formułować pierwsze postulaty dotyczące budowy „państwa dobrobytu”, mającego na celu egalitaryzowanie efektów wzrostu gospodarczego. Nie ulega jednak 
wątpliwości, że współczesna polityka zrównoważonego rozwoju chce sięgać głębiej, a nie skupiać się tylko na rozwoju społecznych funkcji państwa, dlatego kładzie ogromny nacisk na kwestie związane z ochroną środowiska naturalnego, optymalnym gospodarowaniem jego zasobami oraz wszechstronnym rozwojem zasobów ludzkich.

Podsumowując artykuł, możemy przedstawić kilka ogólnych i szczegółowych wniosków:

1) finansowanie celów zrównoważonego rozwoju wymaga stałych i stabilnych dochodów państwa, które mogą zapewnić jedynie zrównoważony wzrost gospodarczy i wysoki poziom umiędzynarodowienia gospodarki;

2) w procesie tworzenia zrównoważonej gospodarki światowej niewątpliwie ogromną rolę odgrywa handel międzynarodowy, stanowiący istotny czynnik determinujący wzrost gospodarczy;

3) efektywny handel zagraniczny jest nie tylko źródłem dochodu narodowego i korzyści skali dla przedsiębiorstw, ale również warunkiem harmonijnego rozwoju wszystkich krajów i narodów, także tych słabiej rozwiniętych i najbiedniejszych;

4) zrównoważony rozwój może skutecznie zapobiegać wykluczeniom i stwarzać warunki do rozwoju wszystkim krajom i narodom, a tym samym podnosić standard życia wszystkich mieszkańców naszej planety.

\section{Bibliografia}

Bluszcz A. (2018), Conditions for Maintaining the Sustainable Development Level of EU Member States, „Social Indicators Research”, nr 139, s. 679-693, https://doi.org/10.1007/s11205-017-1746-6

Brzoska K., Lewandowska A. (2013), Wzrost gospodarczy w dobie zrównoważonego rozwoju [w:] M. Kuczmarska, I. Pietryka (red.), Problemy gospodarki światowej, t. 3, Torun, s. 83-97.

Davidson P. (2012), Rozwiazanie Keynesa: droga do globalnej koniunktury gospodarczej, Warszawa.

Dupuy L. (2014), International Trade and Sustainable Development [w:] G. Atkinson, S. Dietz, E. Neumayer, M. Agarwala (red.), Handbook of Sustainable Development, Cheltenham, s. 399-418.

European Commission (2019), Reflection Paper Towards a Sustainable Europe by 2030, https://ec.europa.eu/commission/sites/beta-political/files/factsheets_sustainable_europe_012019_v3.pdf (data dostępu: 10 listopada 2019).

Eurostat (2018), Sustainable Development in the European Union Monitoring Report on Progress Towards the SDGS in an EU Context. 
Helble M., Shepherd B. (2017), Win-Win: How International Trade Can Help Meet the Sustainable Development Goals, Asian Development Bank Institute. Janicka M. (2016), Financial Markets and the Challenges of Sustainable Growth, „Comparative Economic Research”, nr 19 (2).

Komisja Europejska (2010), Komunikat Komisji Europa 2020. Strategia na rzecz inteligentnego i zrównoważonego rozwoju sprzyjającego włączeniu społecznemu, https://ec.europa.eu/eu2020/pdf/1_PL_ACT_part1_v1.pdf (data dostępu: 10 marca 2020).

Mensah J., Casadevall S.R. (2019), Sustainable development: Meaning, History, Principles, Pillars, and Implications for Human Action: Literature Review, „Cogent Social Sciences”, nr 5 (1).

Mikuła A. (2016), Zrównoważony rozwój w krajach Unii Europejskiej - obszar integracji społecznej, „Konsumpcja i Rozwój”, nr 1 (14), s. 5-18.

Milewski R. (2018), Podstawy ekonomii, Warszawa.

ONZ, Agenda 2030, www.un.org.pl (data dostępu: 6 kwietnia 2020).

ONZ, Commission on Sustainable Development, https://sustainabledevelopment. un.org/csd.html (data dostępu: 2 kwietnia 2020).

Piętak Ł. (2017), Zrównoważony wzrost gospodarczy $w$ teoriach $i$ modelach wzrostu i rozwoju gospodarczego, „Gospodarka w Praktyce i Teorii”, nr 43 (2), s. [51]-77, https://doi.org/10.18778/1429-3730.43.04

Rubaj P. (2013), Międzynarodowa konkurencyjność Szwecji w aspekcie realizacji modelu ,państwa dobrobytu", Lublin.

SDG, Oficjalne statystyki SDG - wskaźniki dla celów globalnych, http://sdg.gov.pl/ (data dostępu: 20 kwietnia 2020).

Stiglitz J. (2016), How to Restore Equitable and Sustainable Economic Growth in the United States, „American Economic Review: Papers \& Proceedings”, nr 106 (5), s. 43-47, http://dx.doi.org/10.1257/aer.p20161006

Tokarski T. (2005), Wybrane modele podażowych czynników wzrostu gospodarczego, Kraków.

Vasile V., Bănică E. (2016), Sustainable Economic Growth Through External Trade, „Annals of the University of Oradea: Economic Science Series”, $\mathrm{nr} 25$ (2), s. $132-145$.

Wojtyna A. (2000), Ewolucja keynesizmu a główny nurt ekonomii, Warszawa.

\section{Streszczenie}

We współczesnych rynkowych systemach gospodarczych zrównoważony rozwój kraju oraz wzrost poziomu dobrobytu jego mieszkańców powinny być nadrzędnymi celami polityki ekonomicznej rządów. Rozwój ten nie jest jednak możliwy bez dynamicznego i stabilnego wzrostu gospodarczego, 
gwarantującego stałe dochody indywidualne i budżetowe. Nieodłącznym elementem nowoczesnej gospodarki jest również jej otwarcie na wymianę i kontakty międzynarodowe, które umożliwiają nie tylko stały wzrost dochodu narodowego, lecz również napływ bezpośrednich inwestycji zagranicznych i nowoczesnych technologii oraz optymalne wykorzystanie zasobów dzięki wykorzystywaniu komparatywnych przewag w handlu. Przedmiotem rozważań tego artykułu jest kwestia powiązań między zrównoważonym rozwojem kraju a jego wzrostem gospodarczym oraz niezbędnym czynnikiem tego wzrostu, jakim jest efektywny handel międzynarodowy.

Słowa kluczowe: zrównoważony wzrost gospodarczy, zrównoważony rozwój, handel międzynarodowy, cele zrównoważonego rozwoju, strategia Europa 2030

\section{Summary}

\section{International trade in terms of sustainable development}

Sustainable development and the growing welfare of society should be the main objectives in the economic policy of each democratic and free-market regime. However, this development is not possible without dynamic economic growth, which guarantees sustainable and stable individual and public incomes. An integral part of each modern economy is its openness to international cooperation and free trade. They generate not only national incomes but also the inflow of foreign direct investments and new technologies, as well as the optimal usage of owned resources in comparative trade. The main purpose of this article is to present the dependence between sustainable development end economic growth, which is accelerated by foreign trade.

Keywords: sustainable development, sustainable growth, foreign trade, aims of Europa 2030 strategy

JEL: F1, F4, I3, O2, O3 